\title{
The Law of Nature, Mosaic Judaism, and Primitive Christianity in John Locke and the English Deists
}

\author{
DIEGO LUCCI \\ American University in Bulgaria
}

\begin{abstract}
In their attempts to revive "true religion," Locke and several English deists, such as Toland, Tindal, Chubb, Morgan, and Annet, focused on the relationship between the Law of Nature, the Law of Moses, and Christ's teaching. However, Locke and the deists formulated different conceptions of the Law of Nature and its relationship with natural religion, Mosaic Judaism, and primitive Christianity. Locke saw the history of human knowledge of morality and religion as a process of gradual disclosure of divinely given truths-a process culminating in Christian revelation. He argued that the Law of Faith, established by Christ, had complemented the Law of Nature and superseded the Law of Moses. Conversely, the deists maintained that the only true religion was the universal, eternal, necessary, and sufficient religion of nature founded on the Law of Nature. They thought that Jesus had merely reaffirmed the Law of Nature, accessible to natural reason, without adding anything to it. Concerning Mosaic Judaism, there were significant differences between Toland and later deists. Toland considered Mosaic Judaism to be on a par with primitive Christianity, since he viewed both the Law of Moses and Christ's precepts as essentially grounded in the Law of Nature. Conversely, Tindal and Chubb judged the ritual prescriptions of the Mosaic Law superseded by Christ's revival of natural religion. Morgan and Annet went even further, for they identified true Christianity with the religion of nature, but criticized Mosaic Judaism as a corruption of natural religion. Briefly, Locke and the English deists aimed to recover true religion from long-lasting distortions. However, their rethinking of the relationship between the Law of Nature, the Mosaic Law, and Christ's message led to different conceptions, uses, and appropriations of natural religion, Mosaic Judaism, and primitive Christianity in their attempts to restore what they perceived as true religion.
\end{abstract}

KEYWORDS Christianity, Deism, John Locke, John Toland, Judaism, Law of Nature, Matthew Tindal, Peter Annet, Thomas Chubb, Thomas Morgan

\section{Introduction}

The concept of the Law of Nature played an important role in the philosophical and religious 
thought of the English Enlightenment, particularly when the relationship between natural and revealed religion was the focus of discussion. This was the case in John Locke's theology and English deism. Both Locke and the deists this article considers-i.e. John Toland, Matthew Tindal, Thomas Chubb, Thomas Morgan, and Peter Annet-argued that natural reason could discover several religious truths, mainly regarding the divinely given Law of Nature and the necessity to abide by this law. They considered adherence to the Law of Nature as a crucial element of true religion, which each of them attempted to revive and recover from long-lasting distortions. However, they had different views of the Law of Nature and its relationship with natural and revealed religion.

Locke believed that God had given humanity a moral law-the Law of Nature-consistent with natural reason. However, he was pessimistic about the actual capacity of unassisted reason to demonstrate moral ideas. Therefore, in The Reasonableness of Christianity (1695), he turned to Scripture to ground morality on solid foundations. According to Locke, Christ not only disclosed the Law of Nature in its entirety, but also complemented it with truths that unassisted reason could not discern on its own-namely, otherworldly rewards and sanctions and God's forgiveness of the repentant faithful. Thus, the Christian Law of Faith, complementing the Law of Nature and superseding the Law of Moses, which included the Law of Nature but was still ineffective to morality and salvation, provided an incentive to act morally and a concrete hope of salvation. Briefly, Locke viewed the history of human knowledge of morality and religion as a process of gradual disclosure of divinely given truths-a process culminating in Christ establishing the Law of Faith, which Locke himself tried to revive against the corruption undergone by Christianity over the centuries.

Unlike Locke, each of the aforesaid deists believed in a religion of nature founded on a Law of Nature perfectly accessible to natural reason. They regarded the religion of nature as universal, eternal, necessary, and sufficient. Accordingly, they argued that Christ had merely confirmed natural religion. Though, they claimed that the religion of nature had suffered from frequent distortions throughout the centuries, both before and after Christ's reaffirmation of the Law of Nature. Appropriating Christ's message to his own philosophy, each of these deists identified primitive Christianity with his own version of natural religion. In describing Jesus as a moral philosopher who had simply restated the Law of Nature without adding anything to it, these authors aimed to grant historical dignity to their respective versions of deism, which they maintained against the ecclesiastical traditions, priestly frauds, and abstruse doctrines that had perverted what Toland called "the original plan of Christianity" (Toland 1999, 156). There is, nevertheless, a significant difference between Toland and later deists. According to Toland, ancient paganisms, Judaism, Christianity, and even Islam were initially all adaptations of the Law of Nature to specific historical circumstances, but were then gradually corrupted by both priestcraft and historical dynamics independent of human will. In Nazarenus (1718), Toland portrayed Mosaic Judaism as being on a par with primitive Christianity, given that both the Law of Moses and Christ's precepts were compatible with, and indeed based on, the Law of Nature. Thus, Toland maintained that Jews, including Jewish converts to Christianity, should keep observing the Mosaic prescriptions, which he described as "expressive of the history of their peculiar nation" (Toland 1999, 160). Tindal, too, regarded the Law of Nature as the foundation of morality and piety. In Christianity as Old as the Creation (1730), he described all just human laws, including the Law of Moses, as "only the Law of Nature adjusted, and accommodated to Circumstances" (Tindal 1730, 53). But Tindal, unlike Toland, considered the Mosaic Law obsolete, because he thought that its ritual 
prescriptions were practicable only in the specific situation of the ancient Hebrews. Chubb was more explicit than Tindal in maintaining that the Mosaic prescriptions, which he defined as "positive institutions" of a particular nation, could and should be discarded after Christ's revival of natural religion (Chubb 1738, 21). The opinion that true Christianity was merely a "republication" of the religion of nature led Morgan and Annet to go even further, for they depicted Mosaic Judaism as a corruption of natural religion. Thus, these two authors decoupled Christianity from Judaism, which they saw as the most emblematic example of "political religion."

If we consider what Samuel Hefelbower termed, exactly a century ago, "the relation of John Locke to English deism" (Hefelbower 1918), the similarities and differences between Locke's and the deists' views on the Law of Nature and its relationship with the Judeo-Christian tradition still need to be properly assessed. Concerning Locke and deism, historiography has indeed concentrated, above all, on Locke's hostility to deism, on some deists' and freethinkers'especially John Toland's and Anthony Collins's-borrowings from Locke's way of ideas, and on the differences between Locke's and the deists' views of reason and revelation. This article aims to fill this gap in historiography by offering a comparative analysis of Locke's and the deists' reflections on the Law of Nature and its relationship with natural religion, Mosaic Judaism, and primitive Christianity. In doing so, this article points out the elements of the Judeo-Christian tradition that Locke and the deists rethought and appropriated in their own philosophical and religious ideas. This article thus calls attention to the similarities and differences between Locke's and the deists' approaches to what they perceived as true religion, the corruption suffered by true religion over the centuries, and the rediscovery and revival of true religion.

\section{The Law of Nature, the Law of Moses, and the Law of Faith in John Locke's Religious Thought}

\section{Morality and Salvation in Locke}

Locke's preoccupation with theological issues, such as God's existence, scriptural authority, the relationship between reason and revelation, and the importance of faith and morality to both salvation and communal life, emerged in his public as well as manuscript writings since at least the 1660s. Locke's theological interests indeed intermingled with, and conditioned, his reflections on knowledge, morality, and politics. Only in his later years, however, did he expound his theological ideas in thorough terms. Locke's later writings on religion, especially The Reasonableness of Christianity and A Paraphrase and Notes on the Epistles of St Paul (1707, posthumous), show that he saw the history of human knowledge of morality and religion as a process of disclosure of divine truths-a process culminating in Christian revelation (Nuovo 2011, 34-39, 2017, 220-25). He judged moral conduct crucial not only to communal life but also to eternal salvation, and he was troubled by the strictly limited stock of knowledge that natural reason can attain in religious and moral matters. Locke's struggle to find the foundations of morality was lifelong, stretching from at least the manuscript Essays on the Law of Nature of 1664 (Locke 1958) to An Essay concerning Human Understanding and beyond (Nuovo 2017, 182-213). His most remarkable attempt at a rational system of ethics is the manuscript Of Ethick in General, written around 1686 and originally intended as the final chapter of the Essay. However, Locke eventually discarded this project and left 
the manuscript incomplete (Locke 2002, 9-14; Nuovo 2017, 193-97). In his effort to ground morality on solid foundations, Locke continually struggled with moral skepticism. He did not question the existence, rationality, and demonstrability of morality in itself. In the Essay, he actually stressed the inherent rationality and objectivity of the Law of Nature and wrote that we "might place Morality amongst the Sciences capable of Demonstration" (Locke 1975, IV.iii.18, 549). Nevertheless, he called attention to the difficulties that natural reason faces when trying to demonstrate moral ideas-difficulties like their unfitness for sensible representation and their complexity (Locke 1975, IV.iii.19, 550-52). He noted that these difficulties "may in a good measure be remedied by Definitions, setting down that Collection of simple Ideas, which every Term shall stand for; and then using the Terms steadily and constantly for that precise Collection" (Locke 1975, IV.iii.20, 552). But he admitted that the limits of human understanding and the frailty of human nature prevent us from demonstrating moral ideas in the same way as we demonstrate mathematical notions (Locke 1975, IV.iii.20, 552). Thus, he was pessimistic about the prospects of enlarging our knowledge of morality through the operation of natural reason. However, he could not surrender to moral skepticism, which he judged to be as harmful as its opposite-namely, allowing religious fanaticism, enthusiasm, and dogmatism to influence civil life (Schneewind 1994, 208). Locke's effort to overcome moral skepticism eventually led him to turn to Scripture in The Reasonableness of Christianity (Moore 1980; Kato 1981, 55-56; Schneewind 1994, 217-18; Wolterstorff 1994, 185; Russo 2001, 168-74; Forster 2005, 40-83; Nuovo 2017, 215-18). In this book of biblical theology, Locke abstained from attempting to ground morality in epistemological foundations. Instead, he aimed to promote moral conduct and the development of moral character on the basis of what he saw as coherent, cogent, Scripture-based theological ethics. In the Reasonableness, he openly acknowledged unassisted reason's failure to provide convincing grounds for morality:

['T] is too hard a task for unassisted Reason, to establish Morality in all its parts upon its true foundation; with a clear and convincing light....['T] is plain in fact, that humane reason unassisted, failed Men in its great and Proper business of Morality. It never from unquestionable Principles, by clear deductions, made out an entire body of the Law of Nature (Locke 1999, 148-50).

Locke argued that the limits of human understanding, the weakness of human nature, and other factors, such as the abuses of words by philosophers, ecclesiastical tradition, priestcraft, and power politics, had always prevented natural reason from grasping the Law of Nature in its entirety (Locke 1975, III.x.2, 490-91, 1999, 161-63; Marshall 1994, 353-57, 405-10; Goldie 2018; Lancaster 2018). This is why God made a covenant with humanity-the covenant of works-establishing the Law of Moses, which consisted of two parts: ritual prescriptions and moral precepts. Locke believed that the ritual prescriptions of the Law of Moses were designed to fit the ancient Hebrews' specific circumstances. As to the moral part of the Law of Moses, Locke called it "the Law of Works" and considered it identical to the Law of Nature (Locke 1999, 16-21). The Law of Works had a significant advantage over the Law of Nature, in that it was easily accessible through Scripture. However, the Law of Moses was still excessively rigorous and did not provide any effective incentive to act morally. For this reason, God made a new covenant with humanity - the covenant of grace or covenant of faith-with which he established the Law of Faith through Christ (Locke 1999, 21-25, 110-12, 132). This new law revolved around what Locke saw as the fundamentals of Christianity-i.e. faith in Jesus as the Messiah, repentance for one's misdeeds, and obedience to the divine moral law. 
When talking of the divine moral law, Locke meant the Law of Nature, which Christ had disclosed in its entirety. To Locke, the Law of Nature was God-given and, hence, universally and eternally valid in all its parts. Given Locke's insistence on the theological foundations and universal and eternal validity of the Law of Nature, his moral and legal thought is expressive of the seventeenth-century natural law tradition-a tradition best exemplified by the works of Hugo Grotius and Samuel Pufendorf. Nevertheless, Locke agreed with the anti-Trinitarian and anti-Calvinist theologian Faustus Socinus and his disciples that Christ had complemented the Law of Nature with two important truths, inaccessible to natural reason alone. Christ indeed assured humankind of otherworldly rewards and sanctions, which were a powerful incentive to act morally:

Thus we see our Saviour not only confirmed the Moral Law;...But moreover, upon occasion, requires the Obedience of his Disciples to several of the Commands he afresh lays upon them; With the enforcement of unspeakable Rewards and Punishments in another World, according to their Obedience, or Disobedience (Locke 1999, 129).

Locke concurred with the Socinians that the Law of Nature alone disposed human beings to preserve their worldly interests, and it was only thanks to Christ that humankind could find a better prospect than earthly benefits-namely, eternal salvation (Wootton 1989, 49). Moreover, Locke followed the Socinians in maintaining that Christ had emphasized God's mercy, thus giving humanity a concrete hope of salvation despite the flaws of human nature. Locke argued that Christ "did not expect.... Perfect Obedience void of all slips and falls: He knew our Make, and the weakness of our Constitution too well, and was sent with a Supply for that Defect" (Locke 1999, 120). This supply was faith: "[B]y the Law of Faith, Faith is allowed to supply the defect of full Obedience; and so the Believers are admitted to Life and Immortality as if they were Righteous" (Locke 1999, 19). Nevertheless, Locke did not believe in salvation by faith alone. Under the Law of Faith, human beings must attempt to behave morally and repent when they sin, although the believer's faith compensates for their failures in the fulfillment of the divine law (Wallace 1984, 53-54). Locke clarified this point when explaining what Christ had required of his followers:

They were required to believe him to be the Messiah; Which Faith is of Grace promised to be reckoned to them for the compleating of their Righteousness, wherein it was defective: But Righteousness, or Obedience to the Law of God, was their great business; Which if they could have attained by their own Performances, there would have been no need of this Gracious Allowance, in Reward of their Faith...But their past Transgressions were pardoned, to those who received Jesus, the promised Messiah, for their King; And their future slips covered, if renouncing their former Iniquities, they entred into his Kingdom, and continued his Subjects, with a steady Resolution and Endeavour to obey his Laws. This Righteousness therefore, a compleat Obedience and freedom from Sin, are still sincerely to be endeavoured after. And 'tis no where promised, That those who persist in a wilful Disobedience to his Laws, shall be received into the eternal bliss of his Kingdom, how much soever they believe in him (Locke 1999, 130).

The repentant faithful who sincerely try to obey the divine law will receive, in Locke's words, "the Pardon and Forgiveness of Sins and Salvation by [Jesus Christ]" (Locke 1999, 
133). Thus, according to Locke, the justifying faith includes good works. To Locke, however, faith, repentance, and obedience-i.e. the fundamentals of Christianity-were necessary but not sufficient to achieve salvation. He argued that every Christian also ought to study Scripture conscientiously. He even admitted the possibility of mistakes about non-fundamentals in interpreting Scripture, and he thought that such mistakes, if made in good faith, would not be injurious to salvation (Locke 1999, 168; Marshall 2000, 172). Nevertheless, Locke believed that Christians, when reading the Bible, could not ignore the aforesaid three fundamentals, which, in his opinion, were plainly delivered in Scripture (Locke 2012, 175). He thought that disregarding the fundamentals of Christianity when reading the Bible was likely to lead to either one of two equally extreme and deplorable, albeit diametrically opposite, outcomesantinomianism and deism (Nuovo 2011, 31-34).

\section{Locke's Anti-Deism}

In the Second Vindication of the Reasonableness, Locke declared that a controversy that had "made so much noise and heat amongst some of the dissenters" had prompted him to make his religious views public (Locke 2012, 34). Although Locke never used the terms "antinomian" and "antinomianism" in the Reasonableness and its two vindications, here he was clearly referring to the antinomian controversy of the 1690s between Independent and Presbyterian theologians. The event that triggered this controversy was the republication, in 1690, of the Civil-War Independent divine Tobias Crisp's Christ Alone Exalted (1643) by his son Samuel (Crisp 1690). As an antinomian, Tobias Crisp argued that the elect were justified solely by God's eternal decree. In Crisp's opinion, good works had no effect on salvation. Locke found this position, which entailed a radical predestinarianism, incompatible with God's justice and goodness and detrimental to both morality and salvation. Locke abhorred not only Crisp's radically predestinarian, antinomian views, but also the very concept of predestination. Although he never used the term "predestination" in the Reasonableness and its vindications, he criticized predestinarianism, which he described as founded on the unscriptural and illogical doctrine of original sin, with the following words at the start of the Reasonableness:

[S]ome Men would have all Adam's Posterity doomed to Eternal Infinite Punishment for the Transgression of Adam, whom Millions had never heard of, and no one had authorized to transact for him, or be his Representative (Locke 1999, 5).

Another reason why Locke disapproved of predestination was that this doctrine had elicited the reaction of others who, overestimating the capacities of natural reason, had fallen into the opposite extreme:

[T]his seemed to others so little consistent with the Justice or Goodness of the Great and Infinite God, that they thought there was no Redemption necessary, and consequently that there was none, rather than admit of it upon a Supposition so derogatory to the Honour and Attributes of that Infinite Being; and so made Jesus Christ nothing but the Restorer and Preacher of pure Natural Religion; thereby doing violence to the whole tenor of the New Testament (Locke 1999, 5).

To Locke, the opinion that Jesus was "nothing but the restorer and preacher of pure natural religion" was a deistic concept. Locke did not use terms like "deism" or "deist" in the Reasonableness, but he wrote the words "deist" or "deists" once in its first vindication and eight times 
in the second. When Locke wrote and published the Reasonableness in 1695, the "deist controversy" in England was still in its germinal phase, although other prominent theologians, such as Richard Baxter and Edward Stillingfleet, had already attacked deism (Baxter 1672; Stillingfleet 1677). Deistic views indeed emerged in England much before the 1690s, especially in the works of the late Renaissance thinker Herbert of Cherbury, whose religion of nature denotes Stoic and Aristotelian influences, and Charles Blount, who largely drew on Herbert's natural religion, Hobbes's materialism and hermeneutics, and Spinoza's monism and biblical criticism (Herbert de Cherbury 1624; Blount 1683a, 1683b). However, the deist controversy raged particularly in the period between the publication of Toland's Christianity Not Mysterious in 1696 and the debates on the works of later deists in the 1730s and 1740s. John Toland and Anthony Collins - a freethinker and a good friend of Locke during the latter's last yearsexpressed monistic and deterministic ideas, indebted to Spinoza's philosophy although even more radical than Spinoza's metaphysics (Mori 2016, 147-72). Conversely, Matthew Tindal and other later deists believed in a transcendent, wise, and benevolent creator and legislator, author of the order of nature and of a moral law comprehensible to natural reason. Despite these differences, all these thinkers shared a strong confidence in the powers of natural reason, a concept of history as a process of corruption of original truth, and a view of institutional religion as the product of socio-cultural, political, merely human dynamics (Lucci 2008b; Hudson 2009b, 2009a; Wigelsworth 2009a).

Locke had good knowledge of Herbert's natural religion, which he criticized as a form of innatism in Book I of the Essay (Locke 1975, I.iii.15-27, 77-84). Nevertheless, nothing in Locke's works shows that he considered Herbert a deist. Concerning Blount, Locke received his works only a week before the publication of the Reasonableness. Therefore, it is unlikely that Locke had this author in mind when he attacked deism in the Reasonableness. It is rather likely that Locke's targets in his attacks on deism in the Reasonableness and its vindications were Uriel Acosta and John Toland (Higgins-Biddle 1999, xxvii-xxxvii). The seventeenth-century heterodox Jewish thinker Uriel Acosta (also called Uriel da Costa) had a conflictual relationship with the Jewish communities of Venice, Hamburg, and Amsterdam, which excommunicated and expelled him several times, because he judged Rabbinic Judaism corrupted by unscriptural beliefs and rituals and devoid of philosophical truth (da Costa 1993). He believed that the Law of Nature was universal, necessary, and sufficient, while he considered institutional religion incompatible with both Scripture and reason. He put an end to his controversial relationship with his co-religionists in 1640, when he committed suicide shortly after completing his autobiography, Exemplar Humanae Vitae. This book remained in manuscript form until Locke's friend, the Dutch Remonstrant theologian Philipp van Limborch published it in 1687 (Limborch 1687, 341-64). Locke knew Acosta's work through Limborch and, in a manuscript note of 1695, he called Acosta "the father and patriarch of the Deists" (Locke 1659-1700, 33). As to Toland, Locke first met him in person in August 1693. Around a year and a half later, Toland sent some papers to Locke through the lawyer John Freke, as two letters from Freke to Locke testify (Locke 1979-1989, vol. 5, nos. 1868, 1874). These papers are lost, but it is likely that they contained the drafts of some sections of Christianity Not Mysterious, which Toland was writing in that period. In this book, Toland concurred with Locke's theory that "it still belongs to Reason, to judge of the Truth of [a proposition] being a Revelation, and of the signification of the Words, wherein it is delivered" (Locke 1975, IV.xviii.8, 694). However, as James Lancaster has observed, Toland diverged from Locke in a significant respect: 
assent to probable matters of fact, Toland argued that assent should only be given to matters of fact that attained the level of the intuitive, not those which were merely probable (Lancaster 2018, 158).

Toland maintained that the "Subject of Faith" must be intelligible to all and must be built upon "very strict Reasoning from Experience" (Toland 1696, 137). As he explained in Christianity Not Mysterious:

When all these Rules concur in any Matter of Fact, I take it then for Demonstration, which is nothing else but Irresistible Evidence from proper Proofs: But where any of these Conditions are wanting, the thing is uncertain, or, at best, but probable, which, with me, are not very different (Toland 1696, 17-18).

Therefore, while Locke classified propositions into three categories-according to reason, above reason, and contrary to reason (Locke 1975, IV.xvii.23, 687)-Toland stated that "there is nothing in the Gospel Contrary to Reason, Nor Above it" (Toland 1696, 77). He added that "an implicite Assent to any thing above Reason...contradicts the Ends of Religion, the Nature of Man, and the Goodness and Wisdom of God" (Toland 1696, 139). Accordingly, he talked of revelation as merely a "means of information," the contents of which ought to be compatible with our "natural" or "common Notions" (Toland 1696, 40-41, 31, 79, 128).

When Stillingfleet accused Locke of having inspired the author of Christianity Not Mysterious and, more specifically, of having enabled him to deny belief in the Trinity as not based on a "clear and distinct idea" (Stillingfleet 1697, 252), Locke protested that he admitted mysteries in religion and that his faith was based on Scripture, not on natural reason alone (Locke 1824a, 30, 95-96, 1824b, 110, 119, 127-30, 1824c, 201-9, 259-70). Locke's insistence on the necessity to consult the Bible when dealing with theological and moral matters denotes his distance from deism. Locke opposed, in particular, the deistic opinion that natural reason, unassisted by divine revelation, actually grasped the Law of Nature completely and perfectly. In the Reasonableness, Locke also argued that the rationalism, circumspection, and elitism of the ancient philosophers who had lived before Christ had promoted the spread of priestcraft:

The Rational and thinking part of Mankind, 'tis true, when they sought after him, found the One, Supream, Invisible God: But if they acknowledged and worshipped him, it was only in their own minds. They kept this Truth locked up in their own breasts as a Secret, nor ever durst venture it amongst the People; much less amongst the Priests, those wary Guardians of their own Creeds and Profitable Inventions. Hence we see that Reason, speaking never so clearly to the Wise and Virtuous, had never Authority enough to prevail on the Multitude (Locke 1999, 144).

As a consequence, according to Locke, "the Priests" ruled "every where, to secure their Empire, having excluded Reason from having any thing to do in Religion" (Locke 1999, 143). Stigmatizing the shortcomings of what Mark Goldie has defined "[t]he lives of pure idolatry and pure reason [which] were both failed projects" (Goldie 2018, 132), Locke made an indirect attack on deism. As Goldie has observed: "Contemporary deist claims for the great capacity of reason, Locke asserts, cannot be sustained in the face of history's evidence to the contrary" (Goldie 2018, 132). To Locke, only Christ reconciled religion and morality, because 
only Christ disclosed the Law of Nature entirely and unambiguously. Moreover, Christ complemented the Law of Nature with an "unquestionable assurance" of otherworldly rewards and punishment and an emphasis on God's mercy, thus offering a strong incentive to act morally and a concrete hope of salvation (Locke 1999, 143-64). Therefore, Locke deemed it convenient to accept the Christian Law of Faith. Conversely, reliance on natural reason alone could only result in a defective morality and was unable to lead to eternal salvation.

\section{Locke's Anti-Judaism}

Locke thought that the Law of Faith had not only explained and complemented the Law of Nature, but also superseded the Law of Moses. According to Locke, the moral part of the Law of Moses-the Law of Works-was identical to the Law of Nature and hence eternally valid, but was still ineffective to motivate moral conduct and lead to eternal salvation. Concerning the ritual prescriptions of the Mosaic Law, Locke distinguished between the Christian concept of "works" and the Mosaic notion of "works of the law" in his rejection of antinomian interpretations of the New Testament, especially of Paul's epistles. In the Reasonableness, Locke argued that Paul had never opposed good works. When Paul spoke against "works," he meant the "works of the law," namely the ceremonial part of the Law of Moses, which was valid only under the old covenant:

[S]ome of God's Positive Commands being for peculiar Ends, and suited to particular Circumstances of Times, Places, and Persons, have a limited and only temporary Obligation by vertue of God's positive Injunction; such as was that part of Moses's Law, which concerned the outward Worship, or Political Constitution of the Jews, and is called the Ceremonial and Judaical law (Locke 1999, 19).

Locke's opinion of the Law of Moses was in line with supersessionism-namely, the Christian doctrine, also called "replacement theology," according to which the Christian Church has succeeded the Jewish people as the definitive people of God. Moreover, Locke subscribed to the so-called "theory of condescension," according to which, as Eldon Eisenach has put it, "the Old Testament law is consigned to the dustbin of history" (Eisenach 1992, 73). In Locke's time, this theory was very popular among many Church of England divines, including Bishop Stillingfleet and Archbishop Tillotson. In the eighteenth century, the Newtonian scholar and clergyman Samuel Clarke unambiguously formulated the basics of this theory in a sermon entitled The End and Design of the Jewish Law: "The Jewish Law was an Institution of Religion adapted by God in great condescension to the weak apprehension of that people" (Clarke 1738, 313). Locke's comments on Judaism and the Jewish people in A Paraphrase and Notes are even more demeaning than Clarke's remarks about the Jews' "weak apprehension" (Reventlow 1984, 283-84; Russo 2002). Paraphrasing Galatians 1:4, in which Paul states that Christ came to "deliver us from this present evil world," Locke wrote that by "evil world" Paul means "the Jewish nation under the Mosaical constitution" (Locke 1987, 1:121). Similarly, commenting on Galatians 3:19-25, Locke maintained that Christ's earthly ministry had marked the end of the Mosaic Law (Locke 1987, 1:138). To Locke, however, "the New Testament or covenant was also, though obscurely, held forth in the law [of Moses]," as he explained in commenting on 2 Corinthians 3:6 ("the letter killeth, but the spirit giveth life") (Locke 1987, 1:278). But Locke believed that a hermeneutic "veil" conditioned the Jews' reading of the Bible, making them unable to discard their literalist, legalistic interpretations of 
the Scriptures and, thus, preventing them from recognizing Jesus as the Messiah and accepting the Christian Law of Faith. He inferred this conclusion from 2 Corinthians 3:15 ("But even unto this day, when Moses is read, the vail is upon their heart"), which he paraphrased as follows: "[E]ven until now when the writings of Moses are read, the veil remains upon their hearts, they see not the spiritual and evangelical truths contained in them" (Locke 1987, 1:280). Even the Jews who joined the Christian community shortly after Christ's Coming did not abandon the "works of the law," thus provoking bitter conflicts among the early Christians (Locke 1987, 2:483). When talking of these "Jewish Christians" in a note to 1 Corinthians 2:6 ("Howbeit we speak wisdom amongst them that are perfect: yet not the wisdom of this world, nor of the princes of this world, that come to nought"), Locke wrote:

St. Paul here tells the Corinthians that the wisdom and learning of the Jewish nation led them not into the knowledge of the wisdom of God, i.e. the Gospel revealed in the Old Testament, evident in this, that it was their rulers and rabbies, who, stiffly adhering to the notions and prejudices of their nation, had crucified Jesus, the Lord of glory, and were now themselves, with their state and religion, upon the point to be swept away and abolished (Locke 1987, 1:174).

According to Locke, Paul had foreseen the destruction of the Jewish nation, state, and religion as a deserved punishment for having crucified Jesus. Locke went so far to justify this "destruction" in a note to Romans 3:8, in which Paul stated that the "damnation" of "some" who had opposed and slandered him was "just." Locke maintained that, by "some," Paul meant the Jews:

"Some." It is past doubt that these were the Jews. But St. Paul, always tender towards his own nation, forbears to name them, when he pronounces this sentence, that their casting-off and destruction now at hand, for this scandal and their opposition to the Christian religion, was just (Locke 1987, 2:506).

Briefly, Locke depicted the Jewish religion as superseded. He considered the Law of Moses still ineffective in its moral part and obsolete in its ceremonial part, which concerned merely "the outward worship or political constitution" of the ancient Hebrews. He thought that the religious and moral development of humankind had culminated in Christ establishing the Law of Faith, which had done away with the Law of Moses. According to Locke, it was not human factors that started and continued this process. He considered this as a process of disclosure of divine truths, for he saw the Law of Nature, the Law of Moses, and the Law of Faith as all Godgiven. Nevertheless, he believed that only the Law of Faith offered humanity a strong incentive for morality and a true hope of salvation. This is why, during his dispute with Stillingfleet in the late 1690s, he refused any association with Toland, whose Christianity Not Mysterious describes revelation as merely a "means of information" about notions comprehensible to natural reason.

\section{The Religion of Nature, Mosaic Judaism, and Primitive Christianity in John Toland's Naturalism}

\section{Toland's Naturalistic Interpretation of Positive Religions}

A republican freethinker and a deist who held a form of monism centered on the concept of 
an intrinsically active matter, the Irish philosopher John Toland wrote several essays concerning the history of religion and the sacred texts of the Judeo-Christian tradition. His historical investigation supported his republicanism and monism in that he described ancient paganisms, Mosaic Judaism, primitive Christianity, and original Islam as fundamentally grounded in a sort of natural religion coinciding, in many respects, with his own philosophical, moral, and political theories (Giuntini 1979; Daniel 1984, 120-58; Champion 1992, 124-32, 1999, 2003, 165-235; Fouke 2007, 228-59; Lucci 2008a, 188-97, 2008b, 65-133). Toland considered theological dogmas, rituals, ceremonies, and ecclesiastical structures as the results of merely historical, socio-cultural, human factors. However, unlike earlier deists, such as Herbert and Blount, Toland believed that not only intentional frauds, priestly schemes, and power politics, but also unintended social, cultural, and political dynamics had produced idolatry, superstition, and belief in mysteries (Champion 1992, 160-69; Lucci 2008b, 91-112).

Toland launched a full-blown attack on mysteries in Christianity Not Mysterious. As I have explained above, this book presents a modified version of Locke's way of ideas, which Locke disapproved of. As Ian Leask has convincingly argued, Christianity Not Mysterious was "profoundly marked, thematically, methodologically, and in terms of 'operative principle', by Spinoza's Theological-Political Treatise" (Leask 2014, 63, 2018b). These two texts converge in their naturalistic treatment of religious ceremonies, in their demystifying analysis of miracles, and in denouncing the political use of mysteries. Moreover, both books deny any special hermeneutical status to the Bible, which Spinoza and Toland read as any other text. In their biblical hermeneutics, these two authors employed exegetical, philological, and historicalcritical methods developed since the Age of Renaissance for the analysis of classical texts. Finally, Toland followed Spinoza in denying that the Gospel is in any sense above reason: as we have seen above, Christianity Not Mysterious makes this point explicitly-much more explicitly than does Spinoza's Tractatus. Christianity Not Mysterious indeed describes Christ as having revealed principles, especially moral principles, perfectly in line with the capabilities of natural reason. In other words, according to Toland, Christ essentially reaffirmed a moral law accessible to natural reason:

[A]ll the Doctrines and Precepts of the New Testament (if it be indeed Divine) must...agree with Natural Reason, and our own ordinary Ideas. This every considerate and wel-dispos'd Person will find by the careful perusal of it: And whoever undertakes this Task, will confess the Gospel not to be hidden from us, nor afar off, but very nigh us, in our Mouths, and in our Hearts (Toland 1696, 46).

Christianity Not Mysterious provoked a harsh and long debate and was even burnt by the public hangman in Dublin. But this did not prevent its author from continuing his career as a heterodox, controversial, widely discussed writer. Toland made his monistic views public in Letters to Serena (1704), in a period when the dualism of Newtonian physico-theology was becoming increasingly influential in English philosophical, scientific, and religious culture, also thanks to the Boyle Lectures. Whereas the fourth and fifth of the Letters to Serena examine (and in part criticize) Spinoza's philosophy, thus expounding Toland's own view of the natural world, the first three letters support his philosophical reflections with a historical analysis of the origins of prejudices, belief in immortality, and idolatry. Following the example of seventeenth-century English scholars, such as John Marsham and John Spencer (Marsham 1672; Spencer 1685), Toland maintained that Egypt was, in ancient times, "the Mother of the Sciences, and its Inhabitants the Parents of all the Arts in Philosophy,...the best Divines then 
in the World" (Toland 1704, 33). He wrote that some of the greatest thinkers of Antiquity, such as Thales, Pythagoras, Anaxagoras, Plato, and the "Persian magi," had learnt the basic tenets of their philosophical systems from the Egyptians (Toland 1704, 29-32). Toland argued that even Mosaic Judaism had its roots in Egyptian wisdom. He rejected the thesis of the Jews' cultural primacy among ancient peoples-a thesis that reinforced eschatological and Christocentric interpretations of human history. The best-known formulation of this thesis is in Demonstratio Evangelica (1679) by the Catholic Bishop Pierre-Daniel Huet. This French churchman maintained that Judaism was the model of all ancient religions, whose deities originated from the source of Moses (Huet 1679). Conversely, according to Toland it was "manifest from the Pentateuch and the Series of other History, that many Nations had their several Religions and Governments long before the Law was deliver'd to the Israelites" (Toland 1704, 20). Toland maintained that the Egyptians and other Middle Eastern peoples had not borrowed religious beliefs and practices from the Jews, who "were of all Eastern People the most illiterate" (Toland 1704, 39). He even rejected the view that Moses was educated in the Jewish tradition:

It is recorded in the Acts of the Apostles for the Honor of Moses, not that he follow'd the Doctrins of Abraham, but that he was educated and had excell'd in all the Learning of the Egyptians. The Pentateuch it self makes mention of their Religion and Sciences long before the Law was deliver'd to Moses, which is an indisputable Testimony of their Antiquity before any Nation in the World (Toland 1704, 39-40).

To Toland, Moses simply elaborated the ancient wisdom he had acquired in Egypt, adapting it to the specific circumstances of the ancient Hebrews. Toland restated this view of Mosaic Judaism in the Latin treatise Origines Judaicae (1709), which Justin Champion has defined "a full-blown assault upon orthodox Christian understandings of Moses as the vir archetypus" (Champion 2003, 174). In this treatise, Toland attempted to refute Huet's theory that Judaism was the source of all ancient religions. He reasserted his thesis that Jewish culture was indebted to Egyptian culture, given that Moses was "one of the Egyptian priests who also governed part of the country" (Toland 1709, 121: here and below, translation mine). According to Toland, Moses despised the polytheism and idolatry that Egyptian wisdom had turned into. Therefore, Moses decided to leave Egypt and was followed by those who approved of his religious and political ideas (Toland 1709, 121-23). Toland depicted Moses as a "pantheist" who believed that "God is what includes us all, and the earth, and the sea, and what we call the sky, and the world, and nature" (Toland 1709, 123). To Toland, Moses was also a republican legislator, able to distinguish between the spheres of politics and religion (Toland 1709, 14853). In order to strengthen his thesis of a "pantheist Moses," Toland referred to various Latin sources, such as the works of Cicero and Tacitus, which highlighted the Jews' abhorrence of religious anthropomorphism and idolatry and emphasized their belief in "the Supreme God, eternal and immutable" (Toland 1709, 155). Toland argued that "Moses had the same opinions as the pantheists," in that Moses believed in the eternity of the universe and never talked of the immortality of the soul or an afterlife with rewards and punishments (Toland 1709, 155-56). Toland deduced from these "opinions" that the Hebrew term "Jehova" stood for "the necessary being,...the incorruptible, eternal, infinite world" (Toland 1709, 156-57). Not only Mosaic Judaism, but also all other ancient religions were originally pure, incorrupt, and founded on unbiased observation of nature, as Toland stated in Letters to Serena: 
The most antient Egyptians, Persians, and Romans, the first Patriarchs of the Hebrews, with several other Nations and Sects, had no sacred Images or Statues, no peculiar Places or costly Fashions of Worship; the plain Easiness of their Religion being most agreeable to the Simplicity of the Divine Nature, as indifference of Place or Time were the best Expressions of infinite Power and Omnipresence (Toland 1704, 71).

In describing the simplicity of ancient religions, Toland employed the deistic leitmotif of sapientia veterum, already utilized by earlier deists, such as Herbert and Blount (Herbert de Cherbury 1996; Blount 1680, 1683b). He followed these authors in claiming that superstition and idolatry had soon arisen and quickly spread among the ancients. Nevertheless, Toland, unlike Herbert and Blount, believed that priestcraft was only one of the reasons for the distortion of ancient wisdom into disparate doctrinal, ceremonial, and ecclesiastical systems. $\mathrm{He}$ thought that many prejudices and superstitions had their origin in socio-cultural dynamics independent of human will (Daniel 1984, 21-59; Fouke 2007, 188-202, 269-94; East 2014). For instance, he argued that idolatry originated in the desire to perpetuate the memory of famous persons, heroes, or important events. This desire led many peoples of Antiquity to impose "on the Stars (as the only everlasting Monuments) the proper names of their Heroes, or of something memorable in their History" (Toland 1704, 74-75). The cult of the stars produced polytheism, although several ancient peoples knew that "most of the Gods were born among them, being Men, who, for their Benefits to the Publick, had obtained immortal honors" (Toland 1704, 76). Superstitious beliefs and practices eventually became deep-rooted among all peoples of Antiquity because "no sort of Prejudices stick closer to us, or are harder to be eradicated, than those of the Society wherein we live and had our Education. This holds equally true of their civil Customs and religious Rites, of their Notions and Practices" (Toland $1704,12)$. Judaism deteriorated into a dogmatic, ritualistic system shortly after Moses' death, because his successors first became superstitious and then tyrannical, thus imposing absurd rituals, obligations, and prohibitions on their subjects (Toland 1709, 127-29). Even Christianity was not immune to this process of corruption, although Jesus had originally attempted to restore true religion:

[A]lmost every Point of those superstitious and idolatrous Religions are in these or grosser Circumstances reviv'd by many Christians....But how little right these have to the Denomination of Christians, who defend the very things which Jesus Christ went about to destroy, is evident to all them who don't consider Christianity as a politick Faction or a bare Sound; but as an Institution design'd to rectify our Morals, to give us just Ideas of the Divinity, and consequently to extirpate all superstitious Opinions and Practices (Toland 1704, 127-28).

\section{Toland's Christian Primitivism and "Philo-Semitism" in Nazarenus and beyond}

Toland attempted to revitalize the principles of primitive Christianity in Nazarenus: or, Jewish, Gentile and Mahometan Christianity, written in 1709-1710, during a period of study in the Netherlands, but published in 1718. The starting point for this book was Toland's discovery, in 1709, of a fifteenth-century Italian manuscript with some annotations in Arabic. This manuscript described the beliefs and customs of the early Christians, also called "Nazarenes" and "Ebionites." These first Christians were mentioned in the writings of only a few Church 
Fathers, such as Tertullian and Epiphanius of Salamis, who considered them as heretics. In the second half of the seventeenth century, their beliefs attracted the attention of several heterodox authors, such as the German anti-Trinitarian Daniel Zwicker, the English anti-clerical writer Henry Stubbe, and the English Unitarian Stephen Nye. According to these authors, the early Christians did not hold Trinitarian views and, instead, considered Jesus as a mere man (Myllykoski 2012; Matar 2014; Lucci 2018, 106, 112-13). Upon reading this Italian manuscript, Toland concluded that it was a translation of the apocryphal Gospel of Barnabas, which, in his opinion, the Muslims had originally adopted as one of their sacred books but had later neglected because of their "excessive veneration...for the Alcoran" (Toland 1999, 142). Toland's identification of this manuscript with the lost Gospel of Barnabas started a debate that is still ongoing, given that several scholars have accepted Toland's hypothesis, at least in part (Ragg and Ragg 1907; Cirillo 1975; Cirillo and Fremaux 1977; Sox 1984). Toland's first work on the alleged gospel was a manuscript in French, Christianisme Judaique et Mahometan, which Justin Champion has accurately described with the following words:

[A] work of learning, bringing together sources of many different ages, languages and categories, [Christianisme Judaique et Mahometan] is relentlessly unforgiving in its assault upon commonplace assumptions. The most obvious difference with much of Toland's public writing is the lack of professed Christian sincerity. Although Toland argues strenuously that current accounts of primitive Christian institutions and doctrine were wrong, he does not attempt to support his critique with the veneer of pious renovatio. While the thrust of Christianisme Judaique et Mahometan is to promote the Ebionite interpretation of the continuity of the first Christian church with the practices of Judaism, this is advanced as historically accurate rather than soteriologically necessary (Champion 1999, 69).

Toland wrote Christianisme Judaique et Mahometan for a private heterodox audience, namely Prince Eugene of Savoy, Baron de Hohendorf, and their intellectual circle in Vienna. This short treatise remained unpublished until 1999, when Champion appended it to his edition of Nazarenus (Toland 1999, 247-86). However, Toland also explained his views on primitive Christianity in Nazarenus, which he wrote for a wider audience. Although presenting a less aggressive tone than Christianisme Judaique et Mahometan, and although being allegedly inspired by the pious intention of Christian renovatio, Nazarenus is still a highly heterodox work. Claiming that the apocryphal Gospel of Barnabas was older and more authoritative than the four canonical Gospels, Toland based his account of primitive Christianity on the Italian manuscript and other non-canonical works. This was not the first time Toland attacked the biblical canon, which he had already questioned in the 1699 tract Amyntor. In this book, he maintained that "the Canon of scripture was established" at the Council of Laodicea in the fourth century, after bitter controversies and without the aid of any "extraordinary revelation" (Toland 1699, 57-58). To substantiate this claim, he added that "there is not one single book in the New Testament which was not refus'd by some of the Ancients as unjustly fathered upon the Apostles, and really forged by their adversaries" (Toland 1699, 61-62). Thus, he included in Amyntor a Catalogue of Books attributed in the Primitive Times to Jesus Christ, His Apostles and other Eminent Persons, which contained a large number of apocryphal works (Toland 1699, 20-41). Moreover, he had good knowledge of a famous collection of apocryphal writings, Codex apocryphus Novi Testamenti (1703), by the German classical scholar and bibliographer Johann Albert Fabricius. In Nazarenus, Toland also referred to several Church Fathers-such 
as Origen, Irenaeus, Justin Martyr, Eusebius, Epiphanius, Jerome, and Augustin-and drew on several modern authors, like the above-mentioned Marsham and Spencer, the English jurist and Hebraist John Selden, the Dutch Orientalist Adriaan Reland, Remonstrant scholars, such as Grotius, Courcelles, and Le Clerc, and still others. As Champion has noted:

Toland in effect used New Testament and patristic sources not as material for authorising a "system" of theological doctrine, but as an historical record of religious practice....The construction of "systems of divinity" and the imposition of these as uniform true belief were no part of primitive practice, but the corrupt establishment of priestcraft (Champion 1999, 75-76).

Toland appropriated Scripture and various early Christian works, also including several apocryphal writings, to his polemic as historical credit. He drew on the alleged Gospel of Barnabas to demonstrate the continuity between Judaism, Christianity, and Islam, about which he wrote:

[T] he Mahometans may not improperly be reckon'd and call'd a sort or sect of Christians, as Christianity was at first esteem'd a branch of Judaism...Jesus did not, as tis universally believ'd, abolish the Law of Moses, neither in whole nor in part, nor in the letter no more than in the spirit: with other uncommon particulars, concerning the true and original Christianity (Toland 1999, 135).

Toland considered these three religions all grounded on a universal moral law-the Law of Nature, which was at the basis of the precepts upheld by Noah and his sons (Toland 1999, 46). The Law of Nature was restated by Moses, many of whose teachings were "no part of the ceremonial Law of the Jews, but a Noachic precept, equally binding all the world upon a moral account" (Toland 1999, 165). Conversely, the ceremonial part of the Mosaic Law was for the Jews alone and aimed at binding their community together:

This Law they look'd upon to be no less national and political than religious and sacred: that is to say, expressive of the history of their peculiar nation, essential to the being of their Theocracy or Republic, and aptly commemorating whatever befell their ancestors or their state; which, not regarding other people, they did not think them bound by the same, however indispensably subject to the Law of Nature (Toland 1999, 160).

Toland repeated this thesis in a short essay appended to Nazarenus and entitled Two Problems, Historical, Political, and Theological concerning the Jewish Nation and Religion (Toland 1999, 235-40). This essay investigates the origins of the "Respublica Mosaica, or the Commonwealth of Moses, which," Toland stated, "I admire infinitely, above all the forms of Government, that ever yet existed" (Toland 1999, 235). Toland compared the Mosaic Law to the legal and political systems of Sparta, Rome, and Venice, and to Plato's Atlantis and Thomas More's Utopia. He argued that the "Commonwealth of Moses" was better than other ancient forms of government, given also that contemporary Jews still observed the Law of Moses (Toland 1999, 235-36). Explaining the origins of the "Commonwealth of Moses," Toland followed such theorists of the "Hebrew Republic" as Sigonius, Cunaeus, and Harrington in describing the ancient Jewish state as founded on rational laws. To Toland, the Mosaic Law distinguished between political power and ecclesiastical authority, endorsed toleration of non-Jews, and provided 
the foundations for a solid republican government. He even maintained that, "if [Jews] ever happen to be resettl'd in Palestine upon their original foundation, which is not at all impossible; they will then, by reason of their excellent constitution, be much more populous, rich, and powerful than any other nation now in the world" (Toland 1999, 240). Toland's "philoSemitism," grounded in a naturalistic interpretation of the Mosaic Law, also informs his plea for Jewish naturalization, Reasons for Naturalizing the Jews in Great Britain and Ireland (1714), written and published in the time of the Hanoverian accession to the British throne. In this pamphlet, Toland borrowed extensively from the Venetian Rabbi Simone Luzzatto's Discorso circa il Stato de gl'Hebrei (1638) in illustrating and praising the rationality, morality, and effectiveness of Jewish Law (Toland 1714, 48-58; Bernardini 1998; Lurbe 1998, 1999; Champion 2000; Karp 2006; Bernardini and Lucci 2012, 35-88; Leask 2018a). Briefly, in both his short essay on "the Jewish Nation and Religion" and his plea for Jewish naturalization, Toland emphatically idealized the "Commonwealth of Moses," which, in the mid-seventeenth century, Harrington, Selden, Milton, and others had placed at the core of English republican thought (Nelson 2010; Sutcliffe 2011). In this regard, Adam Sutcliffe has correctly noted:

[A]lthough Toland sets out...to secularise Jewish history, Judaism persistently eludes a fixed rational analysis, and remains in his texts powerfully charged with mythic significance. While he demystifies Judaism in order to undermine the historical authority of Christianity, he simultaneously remystifies it in new terms, as an originary source of natural religion and as a model of utopian politics (Sutcliffe 2003, 204).

Nevertheless, Nazarenus also addresses the corruption of Mosaic Judaism. According to Toland, the "Legal Ordinances" of the Mosaic Law were necessary to inspire piety among ancient Hebrews. However, "true religion is inward life and spirit," because "Faith...is an internal participation of the divine nature, irradiating the soul; and externally appearing in beneficence, justice, sanctity" (Toland 1999, 117-18). But in ancient times, the Jews "generally mistook the means for the end" (Toland 1999, 118) because their political and religious leaders gradually distorted the meaning of the Law (Toland 1999, 181-82). Therefore, most of them misunderstood Jesus' message, which aimed to restore the true sense of the Mosaic Law. To Toland, "Jesus did not take away or cancel the Jewish Law in any sense whatsoever, Sacrifices only excepted" (Toland 1999, 118). In fact, "there not being one word in any Gospel concerning the abolition of them [i.e. the Mosaic prescriptions], but directly the contrary," Jesus and his Apostles continued "in the practice of the Jewish rites and worship, frequenting the Temple and the Synagogues, observing the solemn feasts and particularly the Passover, like the rest of their Countrymen" (Toland 1999, 161). The Mosaic Law, which contained the same moral precepts as the Law of Nature along with ritual prescriptions, could not cease to exist. In Toland's words, "the Religion that was true yesterday is not false today; neither can it ever be false, if it was once true" (Toland 1999, 178). The relatively few Jews who approved of Jesus' renewal of the Law indeed kept practicing their rites and ceremonies while respecting Jesus' precepts, living in poverty, and sharing their possessions (Toland 1999, 151-53). These first Christians regarded Jesus as "a mere man" who had restated the moral message inherent to the Mosaic Law (Toland 1999, 153). Briefly, Nazarenus portrays both Moses and Jesus as two mere men who reaffirmed the universal moral law, namely the Law of Nature. This book also argues that the Mosaic Law in its entirety, encompassing the moral principles of the Law of Nature and ritual prescriptions designed for the Jewish nation alone, was never 
abolished. Therefore, both Jews and "Jewish Christians"-namely, Jews who had decided to follow Jesus' teachings-were still bound to comply with the Mosaic Law (Fouke 2007, 233-43; Jackson-McCabe 2012b; Jones 2012; Lurbe 2012). Conversely, Gentile converts to Christianity "were not...to observe the Jewish Law," because they were not part of the Jewish nation: they were only required to pursue "the sanctification of the spirit, or the renovation of the inward man," as Jesus had taught (Toland 1999, 117).

According to Toland, the turning point in the history of primitive Christianity was Paul's preaching, which started the corruption of the Christian religion. Toland accused Paul of "having wholly metamorphos'd and perverted" Christianity with philosophical speculations and pagan notions (Toland 1999, 150). Resorting to a leitmotif of anti-Trinitarian theology, also repeated by the English Unitarian Stephen Nye (whose work was among Toland's sources), Toland blamed Paul for having deified Jesus and for having distorted "the original plan of Christianity" (Toland 1999, 155-56). Drawing on Origen, Eusebius, and Epiphanius, Toland observed that the early Christians "call'd Paul an Apostate from the Law; and rejected all his Epistles, as those of an Enemy and an Imposter" (Toland 1999, 150). Moreover, the early Christians rejected Paul's claim to have received direct revelation from God:

These Nazarens therfore or Ebionites were mortal enemies to Paul, whom they stil'd an Apostate... and a transgressor of the Law: representing him as an intruder on the genuin Christianity, and, tho a stranger to the person of Christ, yet substituting his own pretended Revelations to the doctrines of those with whom Christ had convers'd, and to whom he actually communicated his will (Toland 1999, 153).

Nevertheless, Paul's corrupt version of Christianity eventually prevailed because it proved appealing to "Gentile Christians," who found it compatible with the pagan religions they had previously practiced and never completely abandoned:

[T] he true Christianity of the Jews was overborn and destroy'd by the more numerous Gentiles, who, not enduring the reasonableness and simplicity of the same, brought into it by degrees the peculiar expressions and mysteries of Heathenism, the abstruse doctrines and distinctions of their Philosophers, an insupportable pontifical Hyerarchy, and even the altars, offerings, the sacred rites and ceremonies of their Priests, tho they wou'd not so much as tolerate those of the Jews, and yet owning them to be divinely instituted....[T]he Gentiles did likewise introduce into Christianity their former polytheism and deifying of dead men (Toland 1999, 186-87).

Following the early corruption of the Christian religion, the Christian community experienced several controversies and conflicts, during a long process of institutionalization, and further deteriorated due to priestcraft and power politics. According to Toland, a number of early Christian writers contributed to the deterioration of Christianity. In Nazarenus, he referred to the Church Fathers' works not only as historical records of religious practice, but also as sources revealing the doctrinal disagreements and struggles among early Christian writers, most of whom he later accused of priestcraft in a defense of Nazarenus entitled Mangoneutes (Toland 1720, 137-225; Daniel 1984, 125-27). In this essay, written around a decade after Nazarenus and published two years after it, Toland openly blamed the Fathers for having misinterpreted the Scriptures: 
[T]here's nothing on which the Fathers laid their hands that they did not deprave and corrupt, but above all things the sacred Scriptures, which no men in the world were less fit to explain; as appears by their forc'd allegories, delirious etymologies, fanciful allusions, their impertinent and farr-fetch'd interpretations (Toland 1720, 208-9).

Toland's criticism of the Fathers was part of his attack on tradition, which he defined as "the pretence for supporting all the superstition, tyranny, and other abuses, which have so much disfigur'd and perverted Christianity in most parts of the world" (Toland 1720, 209). Accordingly, he maintained that " $[\mathrm{t}]$ is mere illusion, errant sophistry to say...that the Fathers having liv'd nearer than we to the times of the Apostles, they are therefore better interpreters of Scripture"(Toland 1720, xv). Toland argued that modern readers are more knowledgeable, wiser, and less biased than those who lived in the early centuries of Christianity. Therefore, modern readers are better fit to interpret the early documents of Christianity and rediscover "the Religion truly taught by Jesus and the Apostles, stript of all fabulous or superstitious disguises, free from all human additions, mixtures, and inventions" (Toland 1720, 144). Toland reiterated his Christian primitivism several times in Mangoneutes, maintaining that he preferred " $[\mathrm{t}] \mathrm{he}$ Religion taught by Jesus Christ and his Apostles (but not as since corrupted by the subtractions, additions, or other alterations of any particular man or company of men)...before all others" (Toland 1720, 223). In Nazarenus, however, he expressed a sympathetic view of original Islam, which, in his opinion, had reasserted the moral principles of the Law of Nature. But not even Islam, which Toland considered indebted to "the earliest monuments of the Christian religion" (Toland 1999, 135), was immune to the corruption suffered by all positive religions. To Toland, men like Moses, Jesus, and Muhammad essentially revived the universal, necessary, and sufficient religion of nature. Nevertheless, their precepts, which were originally simple, pure, and in line with the Law of Nature, were gradually distorted and eventually forgotten, giving way to baseless rituals, abstruse speculations, and superfluous ecclesiastical structures, all of which proved harmful to true piety and morality. In conclusion, Toland argued that human beings should simply abide by the Law of Nature, regardless of revealed religion and its shortcomings:

[T] he Moral Law was both then, and before, and ever will be, of indispensable obligation to all men, it being the grossest absurdity and impiety to assert the contrary; since sound Reason or the light of common sense, is a catholic and eternal rule, without which mankind cou'd not subsist in peace or happiness one hour. It is the fundamental bond of all society, where there is or there is not a reveal'd religion: and tis the onely thing that's aprov'd by the most opposite Revelations, or by any sort of parties and divisions in each other (Toland 1999, 179).

\section{The Identification of Christianity with Natural Religion and the Roots of Anti-Judaism among Later Deists}

\section{"The Gospel, a Republication of the Religion of Nature": Matthew Tindal's Christianity as Old as the Creation}

As Locke pointed out in his polemic against deists, reliance on natural reason was at the core of deism in its different manifestations—not only Toland's republicanism, monism, and 
naturalistic approach to positive religions, but also the ideas of Matthew Tindal and other eighteenth-century deists who believed in a transcendent, wise, and benevolent creator. In 1730, Tindal, an influential lawyer and writer of political and religious tracts, published a book later labeled "the Bible of Deism," Christianity as Old as the Creation: or, the Gospel, a Republication of the Religion of Nature. In this book, which served as inspiration for other deists, such as Chubb, Morgan, and Annet, Tindal maintained that Christ had simply reaffirmed the Law of Nature. He argued that Christianity was originally nothing but the universal, eternal, necessary, and sufficient religion of nature "republished":

If so, it follows that the Christian Religion has existed from the Beginning; and that God, both Then, and Ever since, has continued to give all Mankind sufficient Means to know it; and that 'tis their Duty to know, believe, profess, and practice it: so that Christianity, tho' the Name is of a later Date, must be as old, and as extensive, as human Nature; and, as the Law of our Creation, must have been Then implanted in us by God himself....If God designed all Mankind shou'd at all times know, what he wills them to know, believe, profess, and practice; and has given them no other Means for this, but the Use of Reason; Reason, human Reason, must then be that Means (Tindal 1730, 4-5).

Tindal and other deists of the mid-eighteenth century believed that God did not need to (and indeed would not) interfere with the order of nature he had created. In their opinion, the presence and efficacy of divine providence in the government of the universe required no suspension of the laws of nature and, hence, no miracles (Reventlow 1984, 374-406; Lalor 2006, 111-40; Lucci 2008b, 169-205; Hudson 2009a, 34-47, 74-100; Wigelsworth 2009a, 151-61, 2009b, 2014; Lucci and Wigelsworth 2015). They thought that the God-given laws of nature were accessible to human reason. They held a similar view of the divine moral law-the Law of Nature-which they judged to be universally and eternally valid, perfectly comprehensible to natural reason, and at the core of natural religion, as Tindal explained in Christianity as Old as the Creation:

By Natural Religion I understand the Belief of the Existence of a God, and the Sense and Practice of those Duties which result from the Knowledge we, by our Reason, have of him and his Perfections; and of ourselves, and our own Imperfections; and of the relation we stand in to him and our Fellow-Creatures: so that the Religion of Nature takes in every thing that is founded on the Reason and Nature of things (Tindal 1730, 11).

To Tindal, the simplicity of the religion of nature allowed all human beings to comprehend and respect it:

True Religion can't but be plain, simple, and natural, as design'd for all Mankind, adapted to every Capacity, and suited to every Condition and Circumstance of Life....Natural Religion...carries its own Evidence with it, those internal, inseparable Marks of Truth (Tindal 1730, 217-18).

According to Tindal, God enabled humankind to understand and practice true religionnamely, natural religion-through natural reason. Therefore, "[t]he Religion of Nature is an 
absolutely perfect Religion; and...external Revelation can neither add to, nor take from its Perfection" (Tindal 1730, 49). Tindal thought that all believers, regardless of their confessional affiliation, deemed observance of the Law of Nature sufficient to salvation:

[A]ll Mankind, Jews, Gentiles, Mahometans, \& c. agree, in owning the Sufficiency of the Law of Nature, to make Men acceptable to God; and...the primitive Christians believ'd, there was an exact Agreement between Natural and Reveal'd Religion; and that the Excellency of the Latter, did consist in being a Republication of the Former (Tindal 1730, 387).

Tindal apparently followed the example of various Church of England divines, including, among others, Archbishop Tillotson and Samuel Clarke, in affirming the compatibility of natural and revealed religion. However, whereas Tillotson, Clarke, and other Church of England divines aimed to show that revealed religion was a necessary complement to the religion of nature, Tindal's strategy reduced revelation to a secondary, superfluous, unnecessary role, as Henning Reventlow has noted:

[A]lthough Tindal sets out to demonstrate in a large-scale system the parallel in content between the religion of nature and the Christian revelation,....his work has in fact demonstrated precisely the opposite.... While we can concede that subjectively, Tindal's intention is to salvage revealed religion, in fact he has only demonstrated the difficulties of discovering its permanent content. Thus ultimately he has shown that revealed religion is superfluous, as the religion of nature is enough for human salvation, and is so much more easily accessible to man (Reventlow 1984, 383).

According to Tindal, Christian revelation was nothing more than a restoration of natural religion, while theological dogmas, religious ceremonies, and ecclesiastical structures largely resulted from priestly frauds and power politics. To Tindal, the Law of Nature, which was at the core of natural religion, was the foundation of true piety and morality. He argued that all just human laws were "only the Law of Nature adjusted, and accommodated to Circumstances" (Tindal 1730, 53). This was also the case with the Law of Moses. Tindal maintained that the Law of Moses consisted of a set of moral principles identical to the Law of Nature and a series of ritual prescriptions designed especially for the ancient Hebrews. Concerning the ceremonial part of the Law of Moses, Tindal noted that, according to "an hundred places" in Scripture, all the precepts "relating to the Jewish Oeconomy...are to last for ever" (Tindal 1730, 390). However, he argued that the ritual prescriptions of the Mosaic Law were practicable only in the specific situation of the ancient Hebrews:

Nor were [other nations] concern'd to know, or when known, oblig'd to observe [the ritual prescriptions of the Jewish Law]; nor did they bind the Jews themselves, but for a time; and even then, they were for the most part impracticable, out of the Land of Canaan (Tindal 1730, 173).

Tindal's opinion that the Mosaic prescriptions are impracticable in modern times implies that these prescriptions can be disregarded as any element of institutional religion (Lucci 2008a, 201-4). Furthermore, Tindal claimed that Judaism, like Christianity, had undergone a process of corruption because of its cunning priests, to such an extent that Jews had become 
"most superstitious" and "most cruel" (Tindal 1730, 134). To Tindal, only the moral precepts of the religion of nature are valid always and everywhere. These precepts also occupied a prominent position in the Mosaic Law and were the very essence of Christianity as taught by Jesus. Conversely, all religious institutions were superfluous, in that they resulted from historical, socio-cultural, human dynamics.

\section{Christ as the Restorer of the Law of Nature: Thomas Chubb's True Gospel of Jesus Christ}

The self-taught deist writer Thomas Chubb shared Tindal's identification of true Christianity with natural religion (Bushell 1967; Reventlow 1984, 384-95; Lucci 2008b, 196-201). In A Discourse concerning Reason (1731) and The Sufficiency of Reason in Matters of Religion (1732), Chubb described natural reason as able to comprehend the Law of Nature and, thus, as a sufficient guide in religious and moral matters. However, Chubb admitted that human reason was "liable to be neglected or abused" (Chubb 1733, 14). This is what happened in ancient times, when the wisdom of the ancients was corrupted by "all the abominable burthensome and hurtful superstitions, and idolatry," particularly when people "committed themselves to the guidance of priests, and oracles, and pretended divine revelations" (Chubb 1733, 14). Therefore, truly divine revelations were needed "to bring [human beings] back to a right use and exercise of their reason in matters of religion" (Chubb 1733, 14). First came "the Jewish revelation," which, nevertheless, "was not intended to be a guide in matters of religion to all our species, but only to the Jewish nation" (Chubb 1733, 12). Then a new, universal revelation-Christian revelation-reaffirmed the Law of Nature. Chubb focused on Christian revelation in The True Gospel of Jesus Christ Asserted (1738) and The True Gospel of Jesus Christ Vindicated (1739). In these books, he embarked on clarifying the meaning of Jesus' message, which he distinguished from the Apostles' teachings and ecclesiastical tradition: "[T]he Gospel of Jesus Christ was that Doctrine which he preached and not any History of Facts, which relate either to his Person or Ministry" (Chubb 1738, 44-45). Chubb argued that Christ's moral teaching was founded on three fundamental principles:

First, [Christ] requires and recommends the conforming our minds and lives to that eternal and inalterable rule of action which is founded in the reason of things (which rule is summarily contained in the written word of God)....Secondly, if Men have lived in a violation of this righteous Law, by which they have rendered themselves highly displeasing to God, and worthy of his resentment, then Christ requires and recommends repentance and reformation of their evil ways, as the only, and the sure ground of the divine mercy and forgiveness. And thirdly, in order to make those truths have the greater impression on the minds and lives of men he declares and assures them that God has appointed a day in which he will judge the world in righteousness, and that he will then either acquit or condemn, reward or punish them according as they have, or have not conformed their minds and lives to that rule of righteousness before-mentioned, and according as they have, or have not repented and amended their evil Ways (Chubb 1738, 18-19).

Chubb saw these principles as elements of the Law of Nature which Jesus had reasserted: "[Christ] was to be, (not the maker, but) the restorer of right paths to dwell (or walk) in" (Chubb 1738, 31). Nevertheless, Christianity started undergoing a process of institutionalization shortly after Christ's death and was soon corrupted with ecclesiastical hierarchies, 
ceremonies, and dogmas like vicarious righteousness and atonement (Reventlow 1984, 38688). Chubb, conversely, upheld an egalitarian view of Christian societies, which he considered free and voluntary. He rejected ecclesiastical authority and argued that the only Christian law is the universal moral law, comprehensible to natural reason and restated by Christ:

Christians as Christians have no other head, that is, they have no other authoritative power or governour over them, but their one common head or governour viz. Christ Jesus our Lord; and they have no other law, considered as Christians, but the laws of Christ to direct their behaviour by (Chubb 1738, 6-7).

Chubb's dislike of ecclesiastical institutions and rituals led him to consider the Law of Christ as distinct from, and even contrary to, the ceremonial part of the Law of Moses:

[T] his law of reason is fitly called the law of Christ, as he specially and strictly requires our compliance with it, and declares that compliance to be the sole ground of divine acceptance, in distinction from, and in opposition to that law of ceremonies or positive institutions which Moses had delivered to the Jews, and which therefore was called the law of Moses (Chubb 1738, 21).

Chubb also claimed that Christ's Apostles—among whom he also included Paul—had made significant efforts to convert Jews from the Law of Moses to the Law of Christ, even by using figurative expressions typical of the Jewish Scriptures when trying to persuade them (Chubb 1738, 146-54). In brief, Chubb believed that Christ's reaffirmation of the Law of Nature in its simplicity, without any ritual prescriptions, had made the ceremonial part of the Law of Moses obsolete and superseded.

\section{Natural Religion and Political Religion according to Thomas Morgan}

Two other deists, Thomas Morgan and Peter Annet, shared Tindal's view of primitive Christianity as a "republication" of the religion of nature. This view led them to make harsh attacks on Mosaic Judaism, which they depicted as an emblematic example of the corruption of natural religion and, hence, as unrelated to Christianity (Reventlow 1984, 372-74, 396406; Jackson-McCabe 2012a; Lucci 2008a, 204-12, 2008b, 187-96, 201-5). In The Moral Philosopher (1737), Morgan, a disaffected Presbyterian preacher turned deist, made a sharp distinction between natural and positive religion:

[T]here are, and always have been, two Sorts or Species of Religion in the World. The first is the Religion of Nature, which consisting in the eternal, immutable Rules and Principles of moral Truth, Righteousness or Reason, has been always the same, and must for ever be alike apprehended by the Understandings of all Mankind, as soon as it comes to be fairly proposed and considered. But besides this, there is another Sort or Species of Religion, which has been commonly call'd positive, institute, or revealed Religion, as distinguish'd from the former. And to avoid Circumlocution, I shall call this the political Religion, or the Religion of the Hierarchy (Morgan 1738, 94).

To Morgan, positive, institutional, "political" religion "has been always different in different Ages and Countries," for it is based on historical, cultural, and social factors even when 
"the several Passions and Interests of every Party, and of every Man, are divinely instituted by immediate Revelation" (Morgan 1738, 95-96). Divergences about the contents of (often alleged) divine revelations have caused widespread enmity and conflicts between believers affiliated to different religious groups. This is the case with Jews and Christians, given that, according to Morgan, "no two Religions in the World can be more inconsistent and irreconcileable, than Judaism and Christianity" (Morgan 1738, 441). Morgan openly blamed those who believed that Christianity was based on Judaism and who, consequently, tried to find similarities between the Old and New Testaments, which he considered extremely different and unrelated to each other (Morgan 1738, 15-19, 441-44). Morgan viewed the Old Testament as a collection of texts covering the history and customs of the ancient Hebrews and written, in an imaginative style, for an uncouth audience, while he followed Tindal's example in describing the Gospel as a republication of the religion of nature. He thought that all peoples of Antiquity had a clear perception of the religion of nature:

The original, true Religion... of God and Nature, consisted in the direct, immediate Worship of the one true God, by an absolute resignation to, and Dependence on him in the Practice of all the Duties and Obligations of moral Truth and Righteousness (Morgan 1738, 230).

However, the spread of idolatry and superstition, triggered by priestcraft and power politics, quickly perverted the original, true religion, particularly in Egypt. Whereas Toland considered Egypt as the source of ancient wisdom, Morgan maintained that, when the Jews lived in Egypt, this country was "the Mother of Superstition, the Parent and Patroness of new Gods, and the Mistress of Idolatry throughout the World. Every new God was a new Revenue to the Priests, and all Nations received their Gods from Egypt" (Morgan 1738, 241-42). The ancient Hebrews soon became "perfectly Egyptianiz'd" (Morgan 1738, 247) and "under this State of Blindness, Obstinacy, and moral Wickedness, Moses brought them out of Egypt, and in the same Condition God left them at last" (Morgan 1738, 259). Even after fleeing from Egypt, the ancient Hebrews retained the superstitious beliefs and idolatrous customs they had contracted in that country:

[A]fter their going out of Egypt..., they could scarce be parallel'd, by any other Nation upon Earth, for their gross Ignorance, Superstition and moral Wickedness, which ran through all their successive Generations, till their final Dissolution and Destruction, while with a most amazing Stupidity and Impudence they continued to claim the Blessings of the Abrahamick Covenant, as God's peculiar People (Morgan 1738, 259).

According to Morgan, Moses was partly responsible for his people's uncouthness and wickedness:

Moses gave them a Law, not as a Law or Religion of Nature, but as the immediate Voice and positive Will of God, the Grounds and Reasons of which they were never to examine or enquire into, nor to look upon it either as founded in the eternal, immutable Fitness of Things, or the Result of any human Wisdom and Prudence. And having this Opinion of their Law in general, they made no Distinction between Morals and Rituals, between eternal, immutable, and temporary and mutable Obligations, or between the Laws of Nature, and the perfect Reverse of them (Morgan 1738, 271). 
To Morgan, "[i]t was not only the Abuses of this Law, but the Law itself, that...was carnal, worldly and deadly, a most intolerable Yoke, or cruel Bondage; and a Constitution that could serve only to blind and enslave those that were under it" (Morgan 1738, 40). Not only Moses, but also "the Prophets were under a Necessity...of accommodating themselves to the Passions, Prejudices, and rooted Superstition of the Nation, or People to whom they were sent" (Morgan 1738, 288). Thus, the Old Testament, written for ignorant and irrational people, led these people even further astray, preventing them from appreciating the simple, pure, rational religion of nature. This is why Jesus' message was necessary to reaffirm the authentic principles of the Law of Nature. At first, the Jews regarded Jesus as their Messiah, but they then repudiated him because, according to their reading of Old Testament prophecies, their Messiah was a temporal prince who would lead them to conquer and rule the world (Morgan 1738, 325-29, 350-54). Conversely, Jesus tried to restore natural religion and, thus, to abolish the Jewish Law (Morgan 1738, 50-80). According to Morgan's reading of the canonical Gospels and Paul's epistles, the Jewish Law was "only an occasional, temporary Thing, never intended for Perpetuity, but to last only for a few Ages" (Morgan 1738, 41). Therefore, Christ's message, far from renewing the Mosaic Law or establishing a new institutional religion, was simply "a Revival of the Religion of Nature" (Morgan 1738, 392). To Morgan, Christ taught that religion is "purely an internal Thing, and consists ultimately in moral Truth and Righteousness, considered as an inward Character, Temper, Disposition, or Habit in the Mind" (Morgan 1738, 416). Nevertheless, Jesus' attempt to restore the religion of nature attracted the hostility of the Jewish religious leaders and earned him martyrdom: "After he had introduced and recommended the true Religion to the World,...he stood to it to the very last, died a Martyr in the Defence of it, and seal'd its Truth with his Blood" (Morgan 1738, 167). Rejecting the satisfaction theory of atonement, Morgan remarked that Christ, whom he described as simply a moral philosopher, was executed because "it was an establish'd Principle with the whole Jewish Nation, that without shedding of Blood there could be no Remission" (Morgan 1738, 163). This principle was interpreted not in a metaphorical sense, but according "to the rigid, literal, and most absurd Sense of the Jewish Law" (Morgan 1738, 165). After Jesus' death, Paul tried to persuade the Jews "to set aside that absurd, tyrannical, blinding and enslaving Law" (Morgan 1738, 52-53) because this law "could be no longer obliging to the Jews any more than to the Gentiles, after they had embraced Christianity" (Morgan 1738, 58). However, Paul met with "Sufferings and Persecutions" which "arose from his struggle as much as possible for natural Right and Reason, against the Superstition of the Christian Jews, and their pretended religious Obligations to the Law of Moses" (Morgan 1738, 80). Unlike Toland, who argued that Paul's preaching had perverted the original plan of Christianity, Morgan talked of Paul in very positive terms:

St. Paul was the great Free-thinker of his Age, the bold and brave Defender of Reason against Authority, in Opposition to those who had set up a wretched Scheme of Superstition, Blindness and Slavery, contrary to all Reason and Common Sense (Morgan 1738, 71).

Morgan believed that it was the influence of Jewish traditions, not Paul's advocacy of the religion of reason, to have perverted primitive Christianity. According to Morgan, the Jewish converts to Christianity "confin'd Salvation to themselves" (Morgan 1738, 367) and distorted Christ's precepts with apocalyptic expectations, dogmatism, and authoritarianism (Morgan 1738, 373-90). In the end, "the Judaizers prevailed, upon St. Paul's Death, and assum'd the 
Name and Dignity of the Catholick Church" (Morgan 1738, 396), thus turning Christianity into a "political religion" (Morgan 1738, 414-20).

Morgan thought that natural reason could rediscover the religion of nature revived by Christ, thus putting an end to the corruption process intrinsic to the history of "political religion." Therefore, he opposed any sort of institutional religion, of which Judaism was a typical manifestation. His criticism of Judaism entailed a condemnation of the Old Testament, which he described as containing an "absurd, tyrannical, blinding and enslaving Law" (Morgan 1738, 52-53). His disparagement of the Old Testament has earned him the label of "a Marcion in his time"(van den Berg 2008, 48). However, Morgan's vilification of the Old Testament was, first and foremost, part of his attack on "political religion," as Henning Reventlow has noted:

The vigour with which Morgan disputes the validity of the Old Testament for Christianity can be explained only in connection with the natural way in which, over the centuries, Old Testament models had been adopted by the established church and constitutional theory had been based on its theology....Therefore Morgan's work also represents a landmark in English intellectual history because it denotes the definitive end of the Old Testament in this role. Though large and imaginative books appeared, to defend it against Morgan,...the days when it had normative validity for the contemporary forms of church and state had gone for ever (Reventlow 1984, 396).

\section{Peter Annet's Attack on Scripture, Mosaic Judaism, and Institutional Religion}

A couple of years after the publication of Morgan's The Moral Philosopher, the schoolmaster Peter Annet, "one of the most aggressive deists that the eighteenth century produced" (Price 1995, v), subjected the biblical text to the cold light of rational examination. In Judging for Ourselves (1739), Annet argued that priestly frauds had caused gross misinterpretations of Scripture, thus leading many people to believe in absurd doctrines like the Trinity and Purgatory (Annet 1739, 6-8). Furthermore, Annet thought that many biblical passages resulted from priestcraft. Accordingly, he maintained that "the Scriptures, however deified, without our own reason, cannot lead us to truth;...they are not all alike worthy of our reception" (Annet 1739, 12). A few years later, in The Resurrection of Jesus Considered (c.1743) and The Resurrection Reconsidered (1744), Annet openly questioned the veracity of Christ's resurrection and the divinely inspired character of Scripture. Utilizing Locke's concept of faith as assent to probable matters of fact, Annet judged the story of Christ's resurrection to "want probability," implying that it was likely that this story was a fabrication of his followers, who were the only witnesses of this event and were all but impartial witnesses (Annet 1744, 41; Lancaster 2018, 159-60). To support this hypothesis, he called attention to the numerous discrepancies between the four canonical Gospels, particularly when the evangelists talk of Jesus' miracles and resurrection. In another book, The History and Character of St. Paul, probably written in the early 1740s, Annet argued that Paul, in his epistles, had added a number of falsities to the fabrications presumably devised by Christ's immediate followers. He depicted Paul as an enthusiast "subject to the Paroxism of a Fever, or a spiritual Fever," a deceiver whose alleged visions of Christ were mere lies, and an impostor guilty of countless frauds (Annet [1742?], 35-42, 48-49, 61-68). Annet accused Paul of having intentionally turned Christianity into a series of meaningless dogmas, given that Paul's epistles support belief in improbable things, such as the Trinity and Christ's resurrection (Annet [1742?], 82-83). Moreover, Annet argued 
that priestcraft had also affected the transmission of the biblical texts, particularly of the New Testament. He maintained that the "probability that these Writings of the four Evangelists had been handed down to us, uncorrupted, thro' so many Languages, Transcriptions, and bad Hands, as they have passed" was "very low," whereas the "probability that they [were] not free from Corruption and Forgery" was "great" (Annet 1743, 15). As James Lancaster has aptly noted, Annet's use of Locke's concept of probability for his own purposes had an unprecedented potential:

Annet's return to the Lockean position recognised, in effect, the subversive potential of probability....The argument that it was improbable that the contents of Scripture were divinely inspired, and thus not worthy of assent, was more subversive because it was a more defensible position (Lancaster 2018, 160).

Dismissing biblical authority altogether, Annet argued "that an historical faith is no part of true and pure religion, which is founded only on truth and purity. That it does not consist in the belief of any history, which whether true or false, makes no man wiser nor better" (Annet 1743, 87). Annet indeed concurred with Tindal and other deists that true Christianity coincided with the religion of nature, which consisted of moral precepts comprehensible to natural reason. In other words, to Annet, as to Tindal, "true Christianity is as old as the Creation" (Annet 1826, 20). Annet made this statement in a periodical he published in 1761, The Free Enquirer. In the nine issues of this periodical, Annet made a new attack on Scripture, this time especially on the Old Testament, and he emphasized the powers of reason in an attempt "not to set up any new Religion, but to illustrate the old which was from the Beginning" (Annet $1826,1)$. He argued that there was no agreement between the religion of nature and Scripture. He was particularly harsh to Moses, whom he blamed for having started the distortion of true religion. Annet maintained that "the Intention of the following Remarks on Moses and his Writings, is not to subvert Christianity...but to show that the Body of it does not stand on the Legs of Judaism, or on any false Bottom which may fail the Building" (Annet 1826, 20). To Annet, true Christianity "was before Judaism, and is independent of it," in that "Christianity is not created in the moveable Sands, which Winds and Waves may blow down and wash away; but...it is built on a Rock; on the Rock of Nature" (Annet 1826, 20). Annet depicted Moses as the author of an irrational religion revolving around the worship of an anthropomorphic and imperfect God: "Thus tyrannical, thus wrathful, and thus revengeful, does Moses represent the all beneficent God" (Annet 1826, 22). Moreover, he portrayed the ancient Hebrews as ignorant people, always ready to consider any unusual event as a miracle and to "easily report and assert, as Truth, what they believe" (Annet 1826, 27). He even compared Moses' alleged miracles to stories in Don Quixote and Gulliver's Travels. To Annet, however, Moses was only the most representative example of deceitful priest. Annet's criticism of Mosaic Judaism was indeed an important element of his attack on institutional religion altogether, as James Herrick has observed:

Annet's criticism is founded on a prominent Deistic hypothesis that the major world religion grew out of struggles for political power in ancient communities. Ancient priests used spiritual coercion to control their tribes or nations, usually claiming both a revelation from God, and miracles to confirm that revelation. Thus, all revealed religion had its origins in political tyranny and thus such religion cannot contribute to spiritual liberation (Herrick 1997, 135-36). 
The fact that Annet expressly targeted Moses and the Scriptures in a periodical intended for a general audience attracted the attention of the authorities. In 1762, the then sixty-nineyear-old Annet was tried for blasphemy before the King's Bench and was sentenced to the pillory and a year's hard labor, besides having to pay a fine. Annet's guilt, in the eyes of his prosecutors and judges, was to have deprived Christianity of its historical and textual foundations, as Herrick has noted:

What he had in fact done was to decouple religion from historical events, to decouple Christianity from Judaism, and to question in caustic fashion the foundational miracles as historical events....Without its crucial foundation in Judaic history, Christianity cannot claim to represent the Messiah promised to the Jews (Herrick 2014, 112).

As Wayne Hudson has pointed out, Annet was "a propagandist for explicit disbelief" whose writings marked the transition from the "Christian deism" of authors like Chubb and Morgan to a more naturalistic outlook (Hudson 2009a, 91). Nonetheless, Annet's conviction that "true Christianity is as old as the Creation" was still in line with Tindal's and the Christian deists' notion of true religion as a universal and eternal system of morality-a system that historical, political, socio-cultural dynamics had perverted into worthless and harmful dogmas, ceremonies, and institutions.

\section{Conclusion}

This article has called attention to the differences between Locke's and the English deists' reflections on the Law of Nature and its relationship with natural religion, Mosaic Judaism, and primitive Christianity. Locke argued that the Christian Law of Faith added a necessary complement to the Law of Nature. He claimed that relying on natural reason alone and hence believing in natural religion (as deists did) or sticking to the superseded Law of Moses (as Jews did) was ineffective to morality and salvation. Consequently, he described a process of gradual disclosure of divinely given moral and religious truths-a process that, unfolding throughout history, culminated in Christian revelation. Conversely, Toland, Tindal, and other English deists of the eighteenth century saw the religion of nature, based on the Law of Nature, as universal and sufficient. Therefore, they identified true religion with natural religion, which Christ had simply confirmed. Each of these deist authors identified his own version of deism with natural religion and, thus, with true Christianity. Judaism was inevitably involved in the connection between natural religion and Christianity according to the aforementioned deists, who reached divergent conclusions concerning this subject. Toland's naturalistic interpretation of the origins and development of positive religions entailed a view of Mosaic Judaism as an adaptation of the Law of Nature to the situation of the ancient Hebrews. Tindal and Chubb too viewed the Law of Moses as designed for the conditions in which the ancient Hebrews lived. However, while Toland maintained the eternal validity of the Mosaic Law in its entirety, encompassing both moral precepts and ritual prescriptions, Tindal and Chubb described the Mosaic prescriptions as superseded by Christ's restoration of the religion of nature. Morgan and Annet went even further in their rejection of the Law of Moses, which they judged "absurd" and "enslaving." Thus, they disassociated true Christianity, which they considered identical to natural religion, from Mosaic Judaism and institutional religion altogether.

Nevertheless, this article has also pointed out some striking similarities between Locke's 
and the deists' attempts to revive what they perceived as true religion. Locke and the aforesaid deists assumed that true, original, uncorrupted religion existed in a distant past-namely, during and immediately after Christ's earthly ministry, or even earlier, among the wise ancients. All of them claimed that Christ's message coincided with true religion-although Locke saw Christ as the Messiah who had revealed true religion ultimately and thoroughly, while the deists viewed Christ as a moral philosopher who had only restored the religion of nature. Both Locke and the deists also argued that true religion had undergone a process of corruption throughout the centuries, due to socio-cultural factors and intentional frauds informing the development of institutional religion. Finally, they appropriated and rethought various elements of the Judeo-Christian tradition, particularly Christ's precepts, to their own philosophical and religious ideas, which each of them described as reviving true religion against long-lasting distortions. This demonstrates that the philosophical or, rather, "ideological" premises of historical investigation often condition its outcomes, even more so when it comes to such a sensitive issue as the rediscovery of religious truths allegedly maintained in a distant past.

\section{Acknowledgments}

This essay is one of the results of a study period I spent at the University of Hamburg from February to July 2018, when I was a Senior Research Fellow of the Maimonides Centre for Advanced Studies (MCAS). I am grateful to the Director of the MCAS, Prof. Giuseppe Veltri, and to all the staff members, research associates, and research fellows of the MCAS for their encouragement, assistance, and interest in my research. I also presented the topic that I cover in this article at the Jewish History Seminar of the Institute of Historical Research, University of London, in October 2018. I am thankful to Adam Sutcliffe and Michael Berkowitz for inviting me to give a presentation on this subject at the IHR. I also thank all participants in this seminar for their questions and comments. Moreover, I am grateful to Raffaele Russo, Jeffrey R. Wigelsworth, and three anonymous reviewers for their insightful comments and helpful suggestions. Finally, I would like to express my gratitude to my home institution, the American University in Bulgaria (AUBG), for its constant support of my research activities.

\section{References}

Annet, Peter. 1739. Judging for Ourselves: Or, Free-Thinking, the Great Duty of Religion. London, UK: printed for the author.

- [1742?]. The History and Character of St. Paul. London, UK: Page.

- 1743. The Resurrection of Jesus Considered. London, UK: printed for the author.

- 1744. The Resurrection Reconsidered. London, UK: printed for the author. . 1826. The Free Enquirer. London, UK: Carlile.

Baxter, Richard. 1672. More Reasons for the Christian Religion, and No Reason Against It. London, UK: Simmons.

Berg, Jan van den. 2008. "English Deism and Germany: The Thomas Morgan Controversy." Journal of Ecclesiastical History 59: 48-61.

Bernardini, Paolo. 1998. "Introduzione." In Ragioni per naturalizzare gli ebrei in Gran Bretagna e Irlanda (1714), by John Toland, edited by Paolo Bernardini, translated by Laura Orsi. Florence: Giuntina. 
Bernardini, Paolo, and Diego Lucci. 2012. The Jews, Instructions for Use: Four Eighteenth-Century Projects for the Emancipation of European Jews. Boston, MA: Academic Studies Press.

Blount, Charles. 1680. Great Is Diana of the Ephesians: Or, the Original of Idolatry, Together with the Politick Institution of the Gentiles Sacrifices. London, UK.

- 1683a. Miracles: No Violations of the Law of Nature. London, UK: Sollers.

. 1683b. Religio Laici: Written in a Letter to John Dryden. London, UK: Bentley and Magnes.

Bushell, Thomas L. 1967. The Sage of Salisbury: Thomas Chubb (1679-1747). New York, NY: Philosophical Library.

Champion, Justin. 1992. The Pillars of Priestcraft Shaken: The Church of England and Its Enemies; 1660-1730. Cambridge: Cambridge University Press.

—. 1999. "Introduction." In Nazarenus, by John Toland, edited by Justin Champion, 1106. Oxford: Voltaire Foundation.

- 2000. "Toleration and Citizenship in Enlightenment England: John Toland and the Naturalization of the Jews, 1714-1753." In Toleration in Enlightenment Europe, edited by Ole Peter Grell and Roy Porter, 133-56. Cambridge: Cambridge University Press.

- 2003. Republican Learning: John Toland and the Crisis of Christian Culture, 1696-1722. Manchester: Manchester University Press.

Chubb, Thomas. 1733. A Discourse Concerning Reason, with Regard to Religion and Divine Revelation. 2nd ed. London, UK: Cox.

- 1738. The True Gospel of Jesus Christ Asserted. London, UK: Cox.

Cirillo, Luigi. 1975. "Un nuovo vangelo apocrifo: Il vangelo di Barnaba." Rivista di storia e letteratura religiosa 2: 391-412.

Cirillo, Luigi, and Michel Fremaux. 1977. Evangile de Barnabe: Recherches sur la composition et l'origin. Paris: Beauchesne.

Clarke, Samuel. 1738. "The End and Design of the Jewish Law." In Works, by Samuel Clarke, 2:307-16. London, UK: Knapton.

Costa, Uriel da. 1993. Examination of Pharisaic Traditions. Translated by H. P. Salomon and I. S. D. Sassoon. Leiden: Brill.

Crisp, Tobias. 1690. Christ Alone Exalted. 2nd ed. London, UK: Marshal.

Daniel, Stephen H. 1984. John Toland: His Methods, Manners, and Mind. Kingston, ON: McGillQueen's University Press.

East, Katherine A. 2014. "Superstitionis Malleus: John Toland, Cicero, and the War on Priestcraft in Early Enlightenment England." History of European Ideas 40: 965-83.

Eisenach, Eldon J. 1992. "Religion and Locke's Two Treatises of Government." In John Locke's Two Treatises of Government: New Interpretations, edited by Edward J. Harpham, 50-81. Lawrence, KS: University Press of Kansas.

Forster, Greg. 2005. John Locke's Politics of Moral Consensus. Cambridge: Cambridge University Press.

Fouke, Daniel C. 2007. Philosophy and Theology in a Burlesque Mode: John Toland and the "Way of Paradox". Amherst, NY: Prometheus.

Giuntini, Chiara. 1979. Panteismo e ideologia repubblicana: John Toland (1670-1722). Bologna: Il Mulino.

Goldie, Mark. 2018. "John Locke, the Early Lockeans, and Priestcraft." Intellectual History Review 28: 125-44. 
Hefelbower, Samuel G. 1918. The Relation of John Locke to English Deism. Chicago, IL: University of Chicago Press.

Herbert de Cherbury, Edward. 1624. De veritate, prout distinguitur a revelatione, a verosimili, a possibili et a falso. Paris.

- 1996. Pagan Religion: A Translation of "De Religione Gentilium". Edited and translated by John A. Butler. Ottawa, ON: Dovehouse.

Herrick, James A. 1997. The Radical Rhetoric of the English Deists: The Discourse of Skepticism, 1680-1750. Columbia, SC: University of South Carolina Press.

- 2014. "Blasphemy in the Eighteenth Century: Contours of a Rhetorical Crime." In Atheism and Deism Revalued: Heterodox Religious Identities in Britain, 1650-1800, edited by Wayne Hudson, Diego Lucci, and Jeffrey R. Wigelsworth, 101-18. Farnham: Ashgate.

Higgins-Biddle, John C. 1999. "Introduction." In The Reasonableness of Christianity, as Delivered in the Scriptures, by John Locke, edited by John C. Higgins-Biddle, xv-cxv. Oxford: Clarendon Press.

Hudson, Wayne. 2009a. Enlightenment and Modernity: The English Deists and Reform. London, UK: Pickering \& Chatto.

—. 2009b. The English Deists: Studies in Early Enlightenment. London, UK: Pickering \& Chatto.

Huet, Pierre-Daniel. 1679. Demonstratio Evangelica. Paris: Michallet.

Jackson-McCabe, Matt. 2012a. “'Jewish Christianity' and 'Christian Deism' in Thomas Morgan's The Moral Philosopher." In The Rediscovery of Jewish Christianity: From Toland to Baur, edited by F. Stanley Jones, 105-22. Atlanta, GA: Society of Biblical Literature.

—. 2012b. "The Invention of Jewish Christianity in John Toland's Nazarenus." In The Rediscovery of Jewish Christianity: From Toland to Baur, edited by F. Stanley Jones, 6790. Atlanta, GA: Society of Biblical Literature.

Jones, F. Stanley. 2012. "The Genesis, Purpose, and Significance of John Toland's Nazarenus." In The Rediscovery of Jewish Christianity: From Toland to Baur, edited by F. Stanley Jones, 91-102. Atlanta, GA: Society of Biblical Literature.

Karp, Jonathan. 2006. "The Mosaic Republic in Augustan Politics: John Toland's 'Reasons for Naturalizing the Jews'." Hebraic Political Studies 1: 462-92.

Kato, Takashi. 1981. "The Reasonableness in the Historical Light of the Essay." Locke Newsletter 12: 45-59.

Lalor, Stephen. 2006. Matthew Tindal, Freethinker: An Eighteenth-Century Assault on Religion. New York, NY: Continuum.

Lancaster, James A. T. 2018. "From Matters of Faith to Matters of Fact: The Problem of Priestcraft in Early Modern England." Intellectual History Review 28: 145-65.

Leask, Ian. 2014. “The Undivulged Event in Toland's 'Christianity Not Mysterious'.” In Atheism and Deism Revalued: Heterodox Religious Identities in Britain, 1650-1800, edited by Wayne Hudson, Diego Lucci, and Jeffrey R. Wigelsworth, 63-80. Farnham: Ashgate.

. 2018a. "Only Natural: John Toland and the Jewish Question." Intellectual History Review 28 (4): 515-28.

- 2018b. "Toland, Spinoza and the Naturalization of Scripture." In Ireland and the Reception of the Bible: Social and Cultural Perspectives, edited by Bradford A. Anderson and Jonathan Kearney, 227-41. London, UK: T\&T Clark. 
Limborch, Philippus van. 1687. De Veritate Religionis Christianae, amica collatio cum erudito Judaeo; acced. Urielis Acosta Exemplar Humanae Vitae, cum Refutatione per Limborch. Gouda: Justum ab Hoeve.

Locke, John. 1659-1700. "Lemmata Ethica, Argumenta et Authores 1659." MS Locke d. 10. Oxford.

. 1824a. "A Letter to the Right Reverend Edward, Lord Bishop of Worcester." In Works, by John Locke, 12th ed., 3:1-96. London, UK: Rivington.

- 1824b. "Reply to the Right Reverend the Lord Bishop of Worcester's Answer to His Letter." In Works, by John Locke, 12th ed., 3:97-185. London, UK: Rivington.

- 1824c. "Reply to the Right Reverend the Lord Bishop of Worcester's Answer to His Second Letter." In Works, by John Locke, 12th ed., 3:192-499. London, UK: Rivington.

- 1958. Essays on the Law of Nature. Edited by Wolfgang von Leyden. Oxford: Clarendon Press.

- 1975. An Essay Concerning Human Understanding. Edited by Peter H. Nidditch. Oxford: Clarendon Press.

— 1979-1989. The Correspondence of John Locke. Edited by E. S. de Beer. 8 vols. Oxford: Oxford University Press.

- 1987. A Paraphrase and Notes on the Epistles of St Paul to the Galatians, 1 and 2 Corinthians, Romans, Ephesians. Edited by Arthur W. Wainwright. 2 vols. Oxford: Clarendon Press.

- 1999. The Reasonableness of Christianity, as Delivered in the Scriptures. Edited by John C. Higgins-Biddle. Oxford: Clarendon Press.

- 2002. Writings on Religion. Edited by Victor Nuovo. Oxford: Oxford University Press. . 2012. Vindications of the Reasonableness of Christianity. Edited by Victor Nuovo. Oxford: Clarendon Press.

Lucci, Diego. 2008a. "Judaism and the Jews in the British Deists' Attacks on Revealed Religion." Hebraic Political Studies 3: 177-214.

- 2008b. Scripture and Deism: The Biblical Criticism of the Eighteenth-Century British Deists. Bern: Lang.

- 2018. "Ante-Nicene Authority and the Trinity in Seventeenth-Century England." Intellectual History Review 28: 101-24.

Lucci, Diego, and Jeffrey R. Wigelsworth. 2015. “'God Does Not Act Arbitrarily, or Interpose Unnecessarily': Providential Deism and the Denial of Miracles in Wollaston, Tindal, Chubb, and Morgan." Intellectual History Review 25: 167-89.

Lurbe, Pierre. 1998. "Introduction." In Raisons de naturaliser les Juifs en Grande-Bretagne et en Irlande, by John Toland, edited by Pierre Lurbe. Paris: Presses universitaires de France.

- 1999. "John Toland and the Naturalization of the Jews." Eighteenth-Century Ireland 14: 37-48.

- 2012. "John Toland's Nazarenus and the Original Plan of Christianity." In The Rediscovery of Jewish Christianity: From Toland to Baur, edited by F. Stanley Jones, 45-66. Atlanta, GA: Society of Biblical Literature.

Marshall, John. 1994. John Locke: Resistance, Religion and Responsibility. Cambridge: Cambridge University Press. - 2000. "Locke, Socinianism, 'Socinianism', and Unitarianism." In English Philosophy in the Age of Locke, edited by M. A. Stewart, 111-82. Oxford: Clarendon Press. 
Marsham, John. 1672. Chronicus canon Aegyptiacus, Hebraicus, Graecus et disquisitiones. London, UK: Roycroft.

Matar, Nabil, ed. 2014. Henry Stubbe and the Beginnings of Islam: The Originall \& Progress of Mahometanism. New York, NY: Columbia University Press.

Moore, J. T. 1980. "Locke on the Moral Need for Christianity." Southwestern Journal of Philosophy 11: 61-68.

Morgan, Thomas. 1738. The Moral Philosopher. 2nd ed. London, UK: printed for the author.

Mori, Gianluca. 2016. L'ateismo dei moderni: Filosofia e negazione di Dio da Spinoza a d'Holbach. Rome: Carocci.

Myllykoski, Matti. 2012. “'Christian Jews' and 'Jewish Christians': The Jewish Origins of Christianity in English Literature from Elizabeth I to Toland's Nazarenus." In The Rediscovery of Jewish Christianity: From Toland to Baur, edited by F. Stanley Jones, 3-41. Atlanta, GA: Society of Biblical Literature.

Nelson, Eric. 2010. The Hebrew Republic: Jewish Sources and the Transformation of European Political Thought. Cambridge, MA: Harvard University Press.

Nuovo, Victor. 2011. Christianity, Antiquity, and Enlightenment: Interpretations of Locke. Dordrecht: Springer.

— 2017. John Locke: The Philosopher as Christian Virtuoso. Oxford: Oxford University Press.

Price, John V. 1995. "Introduction." In A Collection of the Tracts of a Certain Free Enquirer, by Peter Annet, v-xvii. London, UK: Thoemmes.

Ragg, Laura, and Lonsdale Ragg, eds. 1907. The Gospel of Barnabas. Oxford: Clarendon Press.

Reventlow, Henning G. 1984. The Authority of the Bible and the Rise of the Modern World. Translated by John Bowden. London, UK: SCM Press.

Russo, Raffaele. 2001. Ragione e ascolto: L'ermeneutica di John Locke. Naples: Guida. - 2002. "Locke and the Jews: From Toleration to the Destruction of the Temple." Locke Studies 2: 199-223.

Schneewind, J. B. 1994. "Locke's Moral Philosophy." In The Cambridge Companion to Locke, edited by Vere Chappell, 199-225. Cambridge: Cambridge University Press.

Sox, H. David. 1984. The Gospel of Barnabas. London, UK: Allen \& Unwin.

Spencer, John. 1685. De legibus Hebraeorum ritualibus et earum rationibus, libri tres. Cambridge: Chiswel.

Stillingfleet, Edward. 1677. A Letter to a Deist, in Answer to Several Objections Against the Truth and Authority of the Scriptures. London, UK: Pitt.

- 1697. A Discourse in Vindication of the Doctrine of the Trinity. London, UK: Mortlock.

Sutcliffe, Adam. 2003. Judaism and Enlightenment. Cambridge: Cambridge University Press.

— . 2011. "The Philosemitic Moment? Judaism and Republicanism in SeventeenthCentury European Thought." In Philosemitism in History, edited by Jonathan Karp and Adam Sutcliffe, 67-90. Cambridge: Cambridge University Press.

Tindal, Matthew. 1730. Christianity as Old as the Creation: Or, the Gospel, a Republication of the Religion of Nature. London, UK.

Toland, John. 1696. Christianity Not Mysterious. London, UK: Buckley.

- 1699. Amyntor: Or, A Defence of Milton's Life. London, UK.

-1704. Letters to Serena. London: Lintot.

. 1709. Adeisidaemon, sive Titus Livius a Superstitione vindicatus: Annexae sunt ejusdem Origines Judaicae. Den Haag: Johnson. 
1714. Reasons for Naturalizing the Jews in Great Britain and Ireland: On the Same Foot with All Other Nations. London, UK: Roberts.

—. 1720. Tetradymus, Containing Hodegus; ... Clidophorus; ... Hypatia; ... Mangoneutes. London, UK: Brotherton and Meadows.

- 1999. Nazarenus. Edited by Justin Champion. Oxford: Voltaire Foundation.

Wallace, Dewey D. 1984. "Socinianism, Justification by Faith, and the Sources of John Locke's The Reasonableness of Christianity." Journal of the History of Ideas 45 (1): 49-66.

Wigelsworth, Jeffrey R. 2009a. Deism in Enlightenment England: Theology, Politics, and Newtonian Public Science. Manchester: Manchester University Press.

. 2009b. "The Disputed Root of Salvation in Eighteenth-Century English Deism: Thomas Chubb and Thomas Morgan Debate the Impact of the Fall." Intellectual History Review 19: 29-43.

. 2014. "'God Always Acts Suitable to His Character, as a Wise and Good Being': Thomas Chubb and Thomas Morgan on Miracles and Providence." In Atheism and Deism Revalued: Heterodox Religious Identities in Britain, 1650-1800, edited by Wayne Hudson, Diego Lucci, and Jeffrey R. Wigelsworth, 157-72. Farnham: Ashgate.

Wolterstorff, Nicholas. 1994. "Locke's Philosophy of Religion." In The Cambridge Companion to Locke, edited by Vere Chappell, 172-98. Cambridge: Cambridge University Press.

Wootton, David. 1989. “John Locke: Socinian or Natural Law Theorist?” In Religion, Secularization and Political Thought: Thomas Hobbes to J.S. Mill, edited by James E. Crimmins, 39-67. London, UK: Routledge. 